\title{
Rissoid Larvæ as Food of the Young Herring. The Eggs and Larvæ of the Plymouth Rissoidæ.
}

\author{
By \\ Marie V. Lebour, D.Sc., \\ Naturalist at the Plymouth Laboratory.
}

With Plates I-IV.

THE free-swimming young of the Rissoidæ are particularly important in the plankton for there is always one or more species present in any month and they usually occur in great abundance. The various species live between tide-marks, in the laminarian and coralline zones and in deeper water in several fathoms depth ; wherever tow-nettings are taken they usually contain some species of this family. The inshore waters, however, are the richest in rissoids. Even in winter certain species are common round the Plymouth coasts. Some years ago it was found that very young herring just before losing the yolk-sac and about a fortnight old had been eating small rissoids, evidently almost newly hatched (Plate I, Fig. 1). The herring up to a length of about $12 \mathrm{~mm}$. and just after the yolk-sac had disappeared altogether continued to eat them but usually after this size they ate only small crustacea. From 1917 to 1921 it was found that out of 140 young herring examined, 91 had fed on these small gastropods. In later years they were also found feeding on them (Lebour, 1921, 1924). Other minute planktonic organisms were eaten, including algæ, tintinnids, copepod and cirripede nauplii and very small adult copepods ; also a minute bivalve larva but no other gastropod, although other veligers were present in the plankton, Patella being specially common. The young herrings hatch out from December to February, therefore these little gastropods must also hatch at this time and this proves to be the case for in the plankton there are large numbers of these very young veligers (Plate I, Figs. 7-8). Later on, in spring, older stages of the same molluse abound and are quite the commonest veligers in the plankton near the coast (Plate I, Figs. 17-19). In the summer they have almost entirely disappeared.

In order to find out the species it was necessary to make a research on the eggs and larvæ of all the Rissoidæ available. It is now proved that the larva which the herrings eat is Rissoa sarsii Lovén. I have to thank 
Mr. R. Winckworth for confirming this identification. Rissoa sarsii is not known from Plymouth in the adult state, although repeatedly sought, but later larvæ in plunger-jars grew up into this species. Its habitat should be just below low-water mark (Forbes and Hanley, 1853, Vol. III ; Jeffreys, 1867, Vol. IV) and it is probably in a region difficult of access, being just too far out for hand collecting and too far in for dredging. The species, it is now discovered from the Plymouth larvæ, has a characteristic sculpture on the embryonic whorls and it is easy to differentiate it from other near relatives. It is also found, however, that Alvania punctura, living further out, has similar sculpture on the extreme apex although it is easily separated from $R$. sarsii by its other embryonic whorls and it breeds in quite a different season (Plate IV, Figs. 1-7). The sculpture on the apex, not noted by previous workers, points to a very close relationship.

The following is a list of the known Plymouth Rissoidæ, new records being marked with a cross. Some early records are of dead shells only which have not been recorded again. The names are according to Winckworth's recent list of British Marine Mollusca (1932); when these differ from those in the Plymouth Fauna List (Mar. Biol. Assoc., 1931) the latter are added in brackets.

Rissoide. Genus Cingula. Sub-genus Parvisetia, Cingula fulgida (J. Adams) ; $\times$ C. alderi (Jeffreys). Sub-genus Hyala, Cingula vitrea (Montagu) (=Onoba vitrea), dead shells only; C. proxima (Forbes and Hanley) (=Onoba proxima), dead shells only. Sub-genus ONoвa, Cingula semicostata (Montagu) (=Onoba candida). Sub-genus Cingula, Cingula semistriata (Montagu); C. cingillus (Montagu).

Genus Alvania. Sub-genus Manzonia, Alvania crassa (Kanmacher). Sub-genus Alvania, Alvania cimicoides (Forbes), dead shells only; A. cancellata da Costa, dead shells only ; A. zetlandica (Montagu), dead shells only (=Manzonia zetlandica). Sub-genus Galeodina. Alvania carinata (da Costa), dead shells only. Sub-genus Actonia. Alvania punctura (Montagu) (=Arsenia punctura).

Genus Rissoa. Sub-genus Turboella. $\times$ Rissoa sarsii Lovén; $\times$ R. inconspicua Alder; R. parva (da Costa); R. guerini Récluz. Subgenus Rissoa, Rissoa membranacea (J. Adams).

Genus Barleeia. Barleeia unifasciata (Montagu) (=Barleeia rubra).

Of these the eggs have been obtained from Cingula semicostata, C. semistriata, Alvania punctura, Rissoa inconspicua, R. parva, R. guerini, $R$. membranacea and Barleeia unifasciata and the planktonic egg-capsules of Rissoa sarsii have been identified. The larvæ of all these have been distinguished. The veliger stage of Cingula semicostata and Barleeia unifasciata is passed within the egg and the young emerges crawling. Rissoa sarsii is the only species so far known with planktonic egg-capsules. 
The remainder all lay lens-shaped egg-capsules deposited on some substratum which may be regarded as typical of the family.

Jeffreys (1867) states that in Rissoa " the spawn cases are solitary and hemispherical," including in the genus all those now placed in the family Rissoidæ by Winckworth. Jeffreys describes the egg-capsules of Rissoa albella thus: " the spawn cases are generally solitary, semiglobular and light yellowish brown; the fry emerge from a large round hole at the top which appears when they are developed." In his account of the spawn of prosobranchs Lamy (1928) only mentions that of Rissoa membranacea described by Fischer (1892) and of Rissoa parva described by Jeffreys (1867), Caullery and Pelseneer (1910) and Pelseneer (1911). This appears to be all that is known of the spawn of any of the Rissoidæ and these three species $R$. membranacea, $R$. parva and $R$. albella have the typical capsules. The larvæ on hatching have a simple shell consisting of rather more than one whorl, and a well-developed bilobed velum. Until now few observations have been made on the older larvæ.

In the Laboratory Rissoa membranacea laid eggs on Zostera, so also $\operatorname{did} R$. parva, $R$. guerini and Cingula semistriata as well as on other weeds and on the sides of a glass bowl, $R$. inconspicua on weeds and on one another, Alvania punctura on one another. Cingula semicostata laid them singly attached to bits of sand or debris in a glass jar and Barleeia rubra laid single eggs in tough capsules on weed in a bowl. If we examine the mode of life of these species we find that the six species with typical eggcapsules all live on weed with the possible exception of Alvania punctura. It is difficult to be certain of the true habitat of the last species as it is usually found in dredgings where it falls into the fine mud or sand at the bottom. Rissoa membranacea appears always to live on Zostera and since the disease of this plant during the last few years it has disappeared from the Plymouth coast. $R$. parva lives on many weeds, especially the large fronds of Laminaria, R. guerini also lives on various weeds, especially Rhodomela subfusca* and Codium, Cingula semistriata on various weeds and stones below low-water mark. $R$. inconspicua is usually to be found among weeds and on shell gravel below low-water mark, Cingula semicostata on muddy sand and under stones between tide-marks and below low-water mark, Barleeia unifasciata at extreme low tide, especially on Fucus and Calliblepharis jubata, often with Rissoa parva.

The existing classification of the Rissoidæ is very unsatisfactory. Even Thiele (1929) does not notice the embryonic sculpture of our British forms (except Alvania cimicoides which he places in the section Alcinulus in the sub-genus Alvania), although there are certain rissoids described from Australia which have spirally ribbed apices (Thiele, Powell (1930) and

* I am indebted to Mrs. D. P. Wilson for the names of the seaweeds. 
PLATE I.
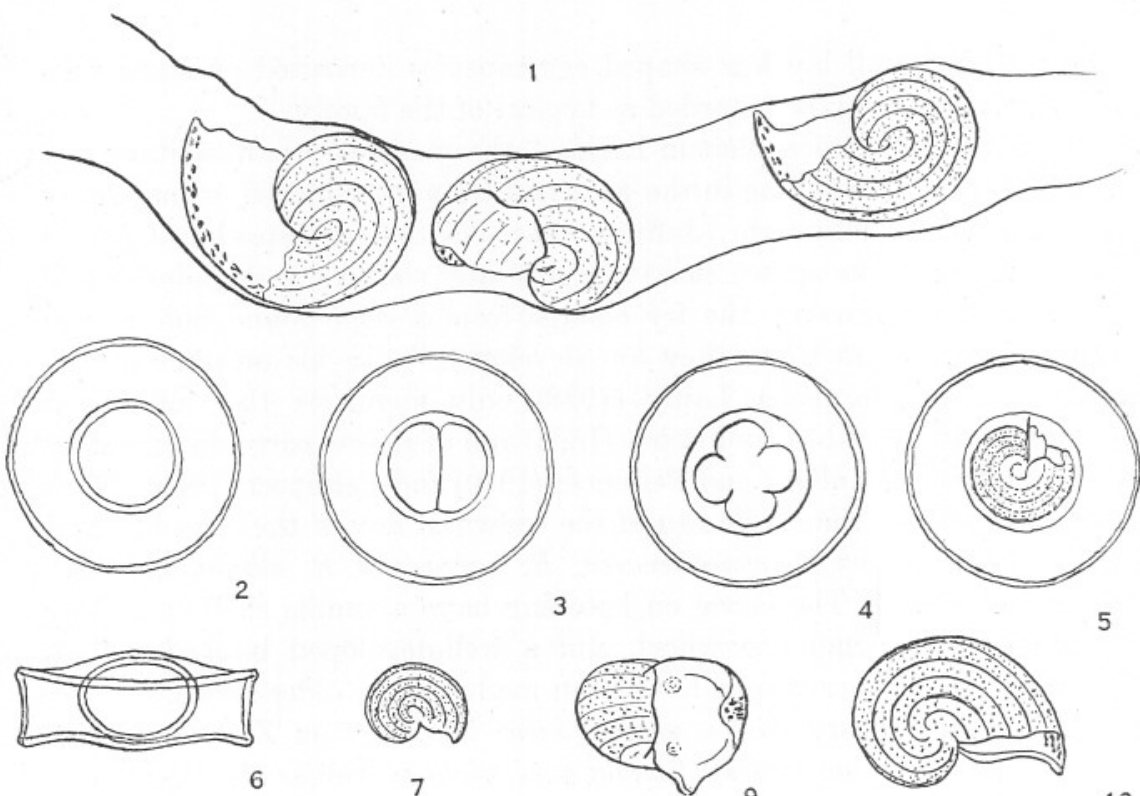

5
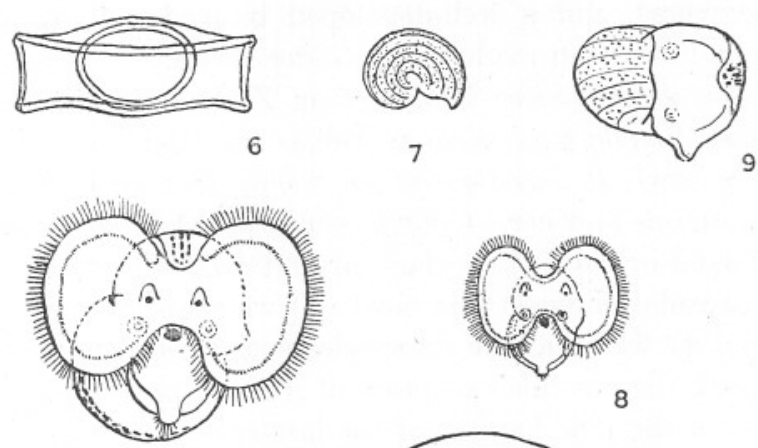

11

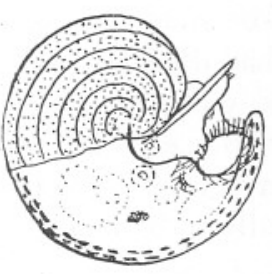

13
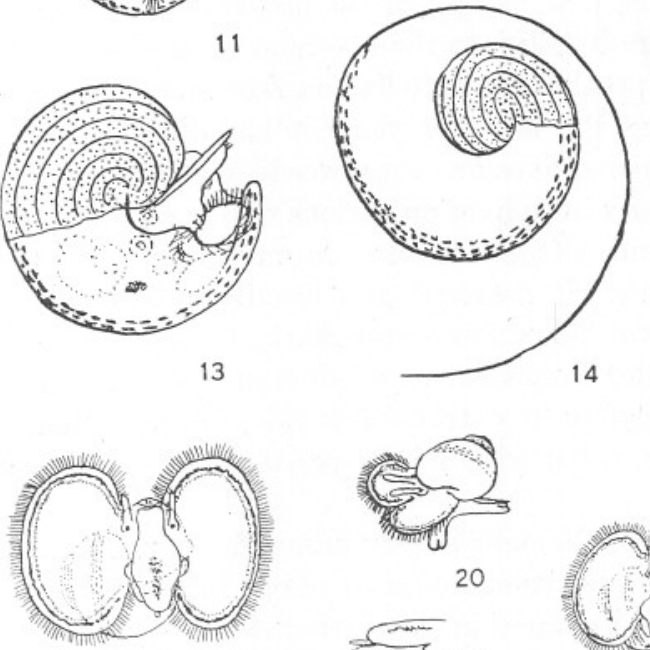

17

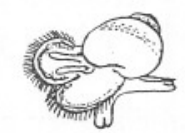

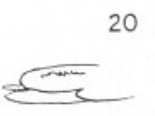

21
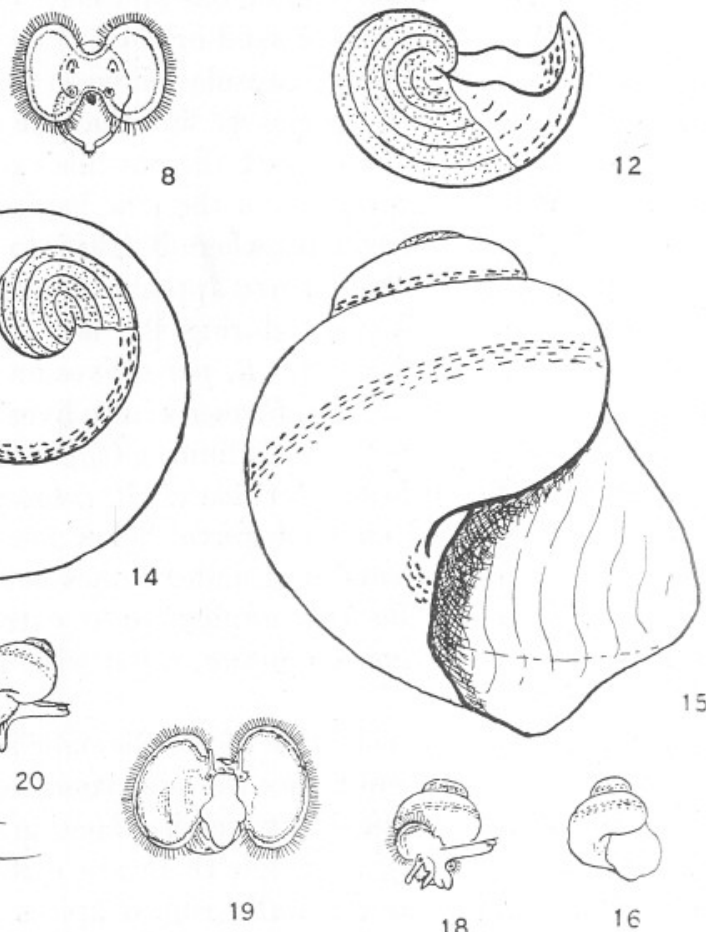

19

18 
others). A smooth apex is the commonest, such as Rissoa membranacea, R. parva, R. guerini, R. inconspicua, Cingula semistriata and Barleeia unifasciata. Cingula semicostata has a finely spirally sculptured apex, whilst Rissoa sarsii and Alvania punctura have spirally sculptured apices with dots in between which are so alike that except for size one could scarcely tell the newly hatched veligers apart should they occur together, which they do not. Surely this must mean a closer relationship than is generally supposed. It would be consistent to place Rissoa sarsii and Alvania punctura at least in the same genus and to remove Cingula semicostata from the genus Cingula for not only is Cingula semistriata very different in the apex, it also, as is well known, possesses three posterior tentacles instead of one. A detailed revision of the genus, both anatomical and conchological, is evidently highly desirable, and one which is helped enormously by the study of the larval stages. Jeffreys (1867) remarks that the embryonic whorls are important and frequently describes them. His only references to sculptured apices in the Rissoidæ are, however, in $R$. Jeffreysii, " the top whorls may be seen to have a few spiral rows of salient and re-entering angles, which last prefigure the cancellated structure of the adult shell," and further on, "the apex is marked with a Vandyke pattern instead of having rows of punctures " (as in Rissoa punctura), and in Rissoa punctura " the uppermost whorls exhibit under the microscope a few rows of punctures." Rissoa cimicoides, $R$. Jeffreysia and $R$. punctura are all now placed in the genus Alvania.

The form of the larval shell of the Rissoidæ is very like that of Lacuna, but the later stages can be distinguished by the shape of the end of the foot, in rissoids pointed, in Lacuna with two lobes. The rissoids have

EXPLANATION OF PLATES.

(The figures are drawn to three scales, B six times A, C twice A )

PLATE I.

Rissoa sarsii.

(Figs. 1-15 scale B, 17 scale C, 16, 18-20 scale A.)

FIG. 1.-Very young larvæ in the intestine of a young herring before completely losing the yolk sac.

Figs. 2-6.-Pelagic egg-capsules, 0.18 mm. across, $(2,6)$ newly laid; (3,4) dividing ; (5) with larva ready to hatch. Larval shell $0.08 \mathrm{~mm}$. across.

Figs. 7-8.-Newly hatched larva, shell $0.08 \mathrm{~mm}$. across.

Fic. 9.-Shell of slightly older larva, $0 \cdot 15 \mathrm{~mm}$. across.

Figs. 10-13.-Older larvæ.

Figs. 14-15.- Shells of older larvæ.

Fias. 16-20.-Late veligers, shell 0.48 mm. high.

FIG. 21.-Foot showing posterior process. 

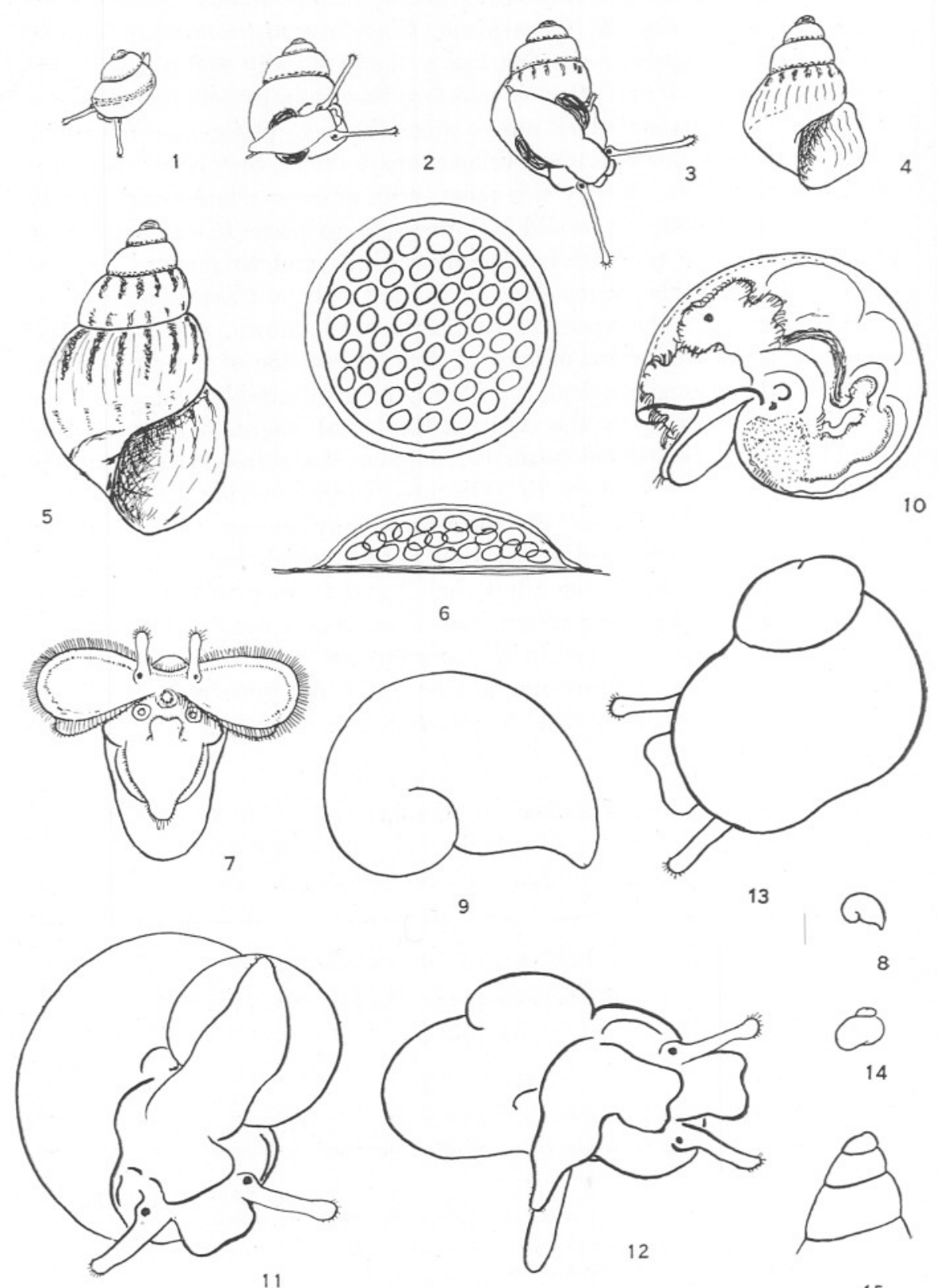
a posterior tentacle, sometimes three, behind the operculum and above the foot, and a pendent tentacle at the upper junction of the inner and outer lip. This last is rarely absent, and in these cases probably has either escaped notice or the species should be placed elsewhere. The various larvæ can be distinguished by the size, absence or presence of sculpture on the embryonic whorls, absence or presence of colour on the velum, length of life in the plankton and general appearanc. Those which remain for some time in the plankton usually have 3 to $3 \frac{1}{2}$ whorls before losing the velum, the posterior and mantle tentacles then being formed and the foot assuming the adult shape.

The following shows the seasonal breeding actually observed at Plymouth :-

January : Rissoa membranacea, R. parva, R. sarsii, Cingula semicostata. February : Rissoa membranacea, $R$. parva, R. guerini, R. sarsii, Cingula semicostata. March : Rissoa membranacea, $R$. parva, R. guerini, R. sarsii, Cingula semicostata. April : Rissoa parva, R. guerini, R. sarsii, Cingula semicostata, C. semistriata, Barleeia unifasciata. May: Rissoa parva, R. guerini, R. sarsii, Cingula semistriata, Barleeia unifasciata. June: Rissoa parva, Cingula semistriata, C. semicostata. July: Rissoa guerini, Cingula semistriata. August: Rissoa guerini, Alvania punctura, unknown rissoid. September : Rissoa parva, R. guerini, Alvania punctura, unknown rissoid. October: Rissoa parva, R. guerini, R. inconspicua, Alvania punctura. November: Rissoa parva, R. guerini, R. inconspicua, Alvania punctura, unknown rissoid. December: Rissoa parva, $R$. guerini, $R$. sarsii, R. membranacea, Cingula semicostata.

\section{Rissoa membranacea ( $\mathrm{J}$ Adams).}

(Plate II, Figs. 6-15).

The largest of the Plymouth rissoids, usually occurring abundantly on Zostera marina on the Zostera beds. Egg-capsules of typical lens-like form, flat on the attached surface, rounded above. Actually seen from

\section{PLATE II.}

Rissoa sarsii, Rissoa membranacea.

(Figs. 1-6, 8-15 scale A ; 7-13 scale B.)

FigS. 1-5.-Rissoa sarsii reared from planktonic larvæ, shell $0.48 \mathrm{~mm}$. to $2 \mathrm{~mm}$. high.

Figs. 6-15.-Rissoa membranacea.

FiG. 6.-Egg capsule, $1.5 \mathrm{~mm}$. across.

Figs. 7-8.-Newly hatehed larva, shell 0.32 mm. across, from egg.

Figs. 9-10.-Larvæ a few days old, reared in bowl.

Figs. 11-14.-Young crawling, reared in bowl, shell $0.37 \mathrm{~mm}$. across.

FIG. 15.-Apex of adult shell. 
PLATE III.

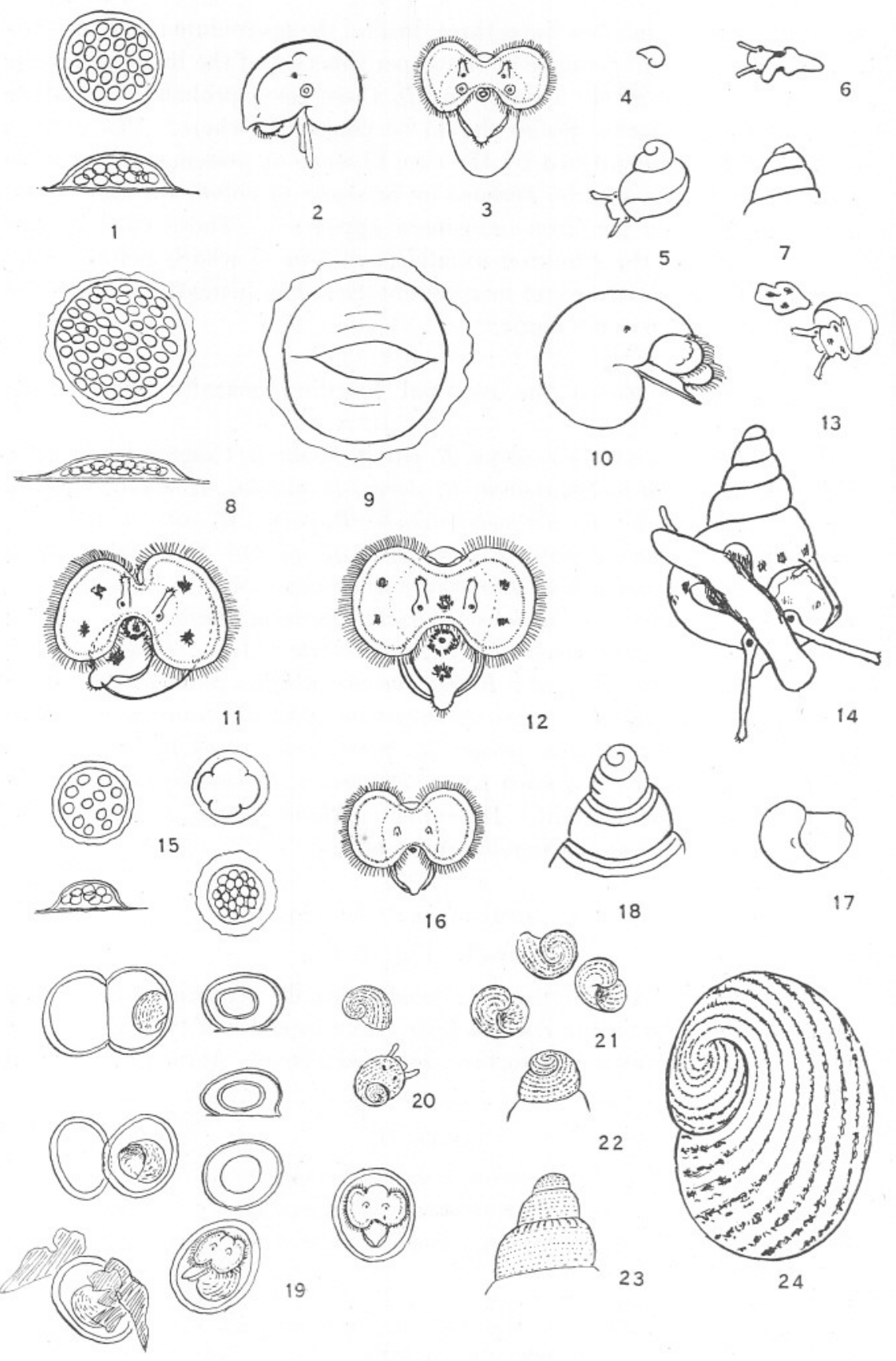


December to March but breeding probably goes on through spring and summer as it does on the French coast. Some eggs were laid on Zostera in bowls during December and January. Fischer (1892) figures the spawn from Arcachon and describes it as watch-glass shaped, about $1.5 \mathrm{~mm}$. across, with about 100 eggs, which, when ready to hatch, escape from a hole at the top formed when the larvæ are developed sufficiently to swim away. The Plymouth specimens agree in size, capsules 1.4 to $1.6 \mathrm{~mm}$. across, 0.32 mm. high (Plate II, Fig. 6), but do not contain so many eggs. From 40 to 60 , about $0 \cdot 13 \mathrm{~mm}$. across, is the usual number, and these did not all develop, several being apparently devoured by their neighbours. This may or may not be a case of true " nurse " eggs, for possibly the eggs in captivity were abnormal. In about 10 to 12 days the eggs hatched as free-swimming veligers, $0.32 \mathrm{~mm}$. across the round, transparent and colourless shell of about $1 \frac{1}{2}$ whorls without sculpture (Plate II, Fig. 7). Animal, including velum, colourless, velum $0.32 \mathrm{~mm}$. across, foot short, not reaching behind to end of shell, front part with process but not reaching mouth. Tentacles, eyes, otocysts and mouth well developed. The larvæ in a bowl with Nitzschia grew very quickly, front of foot soon covering mouth and in about 3 weeks or less were crawling, having lost velum. Larvæ hatched December 12th were crawling January 5th, shell about $0.37 \mathrm{~mm}$. across and still without sculpture. The species can be recognised easily at this stage. Although when newly hatched it is larger than any of the rissoids known, it loses the velum at a smaller size and with fewer whorls than most of the others, having hardly $2 \frac{1}{2}$ whorls at metamorphosis (Plate II, Figs. 11-14). Capsules and larvæ were found in their natural surroundings on and near Zostera in spring.

\section{PLATE III.}

Rissoa parva, Rissoa guerini, Cingula semistriata, Cingula semicostata.

(Figs. 1, 4-9, 13-15, 18-23 scale A ; 10-12, 16, 17, 24 scale B.)

Figs. 1-7.-Rissoa parva.

(1) egg-capsules laid in bowl, $0.64 \mathrm{~mm}$. across ; (2-4) newly hatched larvæ from eggs, shell $0 \cdot 13 \mathrm{~mm}$. across ; (5) young just crawling, having lost velum, shell $0.48 \mathrm{~mm}$. high ; (6) foot of same ; (7) apex of adult shell.

Figs. 8-14.--Rissoa guerini.

(8-9) egg-capsule laid in bowl, (8) newly laid with eggs, capsule $0.96 \mathrm{~mm}$. across ; (9) empty capsule showing hole from which the larvæ have emerged, capsule $0 \cdot 14 \mathrm{~mm}$. across ; (10) newly hatched larva from egg, shell $0.16 \mathrm{~mm}$. across; (11-12) slightly older veligers, reared from egg ; (13) young shell from red weed, crawling; (14) halfgrown shell.

Figs. 15-18.-Cingula semistriata.

(15) egg-capsules laid in bowl, $0 \cdot 64 \mathrm{~mm}$. across ; (16-17) newly hatched larva from egg, shell $0 \cdot 10 \mathrm{~mm}$. across ; (18) apex of adult shell.

Figs. 19-24.-Cingula semicostata.

(19) egg-capsules laid in glass jar, $0.48 \mathrm{~mm}$. across; (20) young newly hatched, shells $0.30 \mathrm{~mm}$. across; (21) slightly older shells; (22) apex af half-grown shell; (23) apex of adult shell; (24) young shell much enlarged. 


\section{Rissoa parva (Da Costa).}

(Plate III, Figs. 1-7).

The commonest of all the rissoids, occurring abundantly between tidemarks and below on all parts of the coast, laying eggs on seaweeds where it lives. Pelseneer (1911) states that its spawn is abundant in spring and summer on red algæ (Callithamnium, Griffithsia, etc.) on the Brittany coast, capsules about $1 \mathrm{~mm}$. in diameter, transparent and colourless, and contain from 6 to 35 eggs. Near Plymouth it lays eggs on both brown and green weeds, especially in the rock pools exposed at spring tides, where it is present in huge numbers, both the type and the var. interrupta. It appears to breed most of the year but chiefly in spring and summer, Veliger is usually to be found in the plankton, attaining 3 to $3 \frac{1}{2}$ whorls before losing velum. Specimens in bowls laid eggs on Zostera, December 4th. Capsules similar to those of $R$. membranacea but much smaller and higher in proportion to the width. Diameter 0.64 mm., height $0.30 \mathrm{~mm}$., containing from 20 to 50 eggs, about $0.09 \mathrm{~mm}$. across (Plate III, Fig. 1). All the eggs hatched out in about 10 days. Larva very like $R$. membranacea but smaller, $0 \cdot 13 \mathrm{~mm}$. across shell when newly hatched (Plate III, Figs. 2-3) with $1 \frac{1}{2}$ whorls, colourless, transparent, without. sculpture. Velum colourless, about $0 \cdot 13 \mathrm{~mm}$. across. Eyes, otocysts, mouth and foot well developed but no front process to foot at first. Veliger alters little but grows quickly, foot becoming brownish and later having the dark purplish brown markings at junction with body on each side, velum remaining colourless but growing large, more than twice width of shell; body whorl (third) of late larva with fine line round periphery. Shell now $0.48 \mathrm{~mm}$. long. Animal can now swim or crawl (Plate III, Figs. 5-6). Velum disappears and little Rissoa is like adult except for colouring which begins to be a pale horn-colour and even on third whorl at top of outer aperture on outside is a faint indication of the brown falciform mark separating this species from all others.

\section{Rissoa gueRINI RÉCLUZ.}

(Plate III, Figs. 8-14).

Fairly common round Plymouth coast among weeds at extreme low water and below, chiefly off Drake's Island in Sound. One specimen in bowl laid 2 egg-capsules on February 16th on Zostera. Later on the same animal laid several more capsules on the sides of the bowl, through February, March and April. First capsule $0.96 \mathrm{~mm}$. across, $0.16 \mathrm{~mm}$. high (Plate III, Fig. 8), thin-walled, colourless and transparent, containing about 80 eggs, $0.09 \mathrm{~mm}$. across. Some of the later capsules are larger, $1.1 \mathrm{~mm}$. across, with a broad margin making the whole $1.4 \mathrm{~mm}$. (Plate III, 
Fig. 9). The larvæ escaped in 10 days leaving a large hole at the top of the capsule and swam away as veligers. Larval shell $0 \cdot 16 \mathrm{~mm}$. across when newly hatched with about $1 \frac{1}{2}$ whorls, colourless, transparent, without sculpture; animal and velum also colourless at first, velum $1.2 \mathrm{~mm}$. across (Plate III, Fig. 10). Shell rather more compact than $R$. membranacea and $R$. parva, slightly smaller. In a few days velum becomes characteristically spotted with dark brown (Plate III, Figs. 11, 12), spots also on body, 2 on each of velar lobes, one in centre between eyes, one in centre at base of foot and brown pigment round mouth. Veligers in this stage occur in plankton and also later stages in which colour has increased; foot yellowish brown with dark spots, velum bordered with brown spots more or less irregular. As soon as pigment appears, larva easy to distinguish. Metamorphosis when there are about 3 to $3 \frac{1}{2}$ whorls ; no pattern on shell until about 5th whorl which suddenly enlarges and has brown spots round periphery (Plate III, Fig. 14).

\section{Rissoa inconspicua Alder.}

(Plate IV, Figs. 13-15.)

Fairly common on sandy gravel in parts of Sound, and among weeds, close to coast or beyond. Jeffreys (1867) has recorded it as common in trawl refuse at Plymouth but in those days this was brought close inshore, a practice now discontinued. It is still to be found sometimes in trawl waste and later stages just metamorphosed are sometimes in tow-nets from both inside and outside Sound. Most frequent off White Patch, on east of Sound, close to shore, beyond low-water mark. Adults from here laid eggs in bowls on Zostera and also on one another and on pieces of debris. Egg-capsules small, $0.48 \mathrm{~mm}$. to $0.64 \mathrm{~mm}$. across, sometimes smaller, about $0 \cdot 12 \mathrm{~mm}$. high, clear and colourless, containing about 6-9 eggs, 0.08 mm. across when newly laid. Young hatch as veligers in 10 days; shell smooth, unsculptured, about $0.10 \mathrm{~mm}$. across ; velum colourless at first, about $0 \cdot 10 \mathrm{~mm}$. across; foot, eyes, otocysts and tentacles all present. Velum later bordered with brown; older larvæ with two faint spiral lines round body whorl. These are common in early autumn. Newly metamorphosed shells have the purple apex characteristic of the adult, but there is no sculpture on the first 3 whorls except a slight spiral broken line just above periphery of third whorl.

\section{Rissoa sarsil Alder.}

(Plate I, Figs. 1-16; Plate II, Figs. 1-5.)

Eaten when very small by young herrings (see page 523). Larvæ recognised in egg-capsules from which veligers were hatched. Later 
PLATE IV.
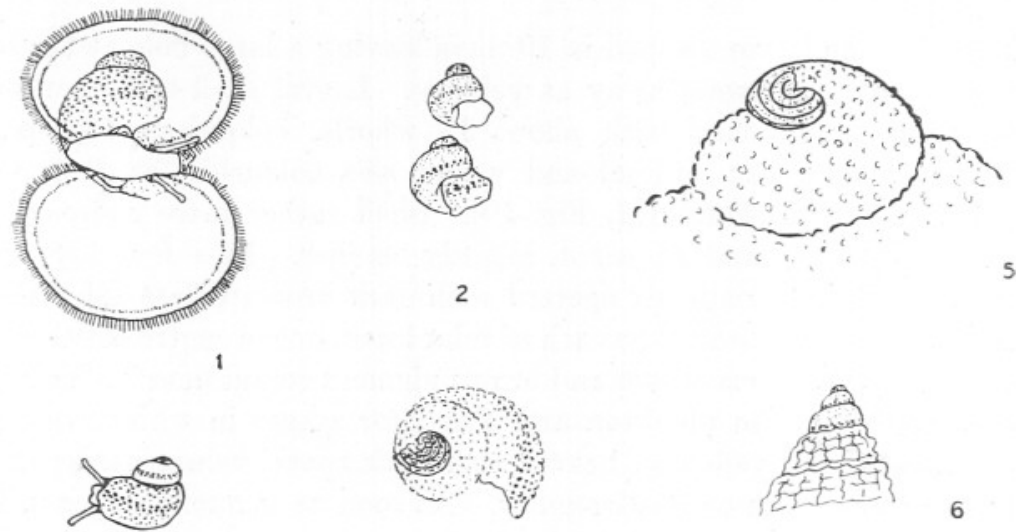

3

4

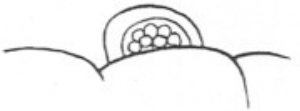

7

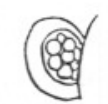

(2)
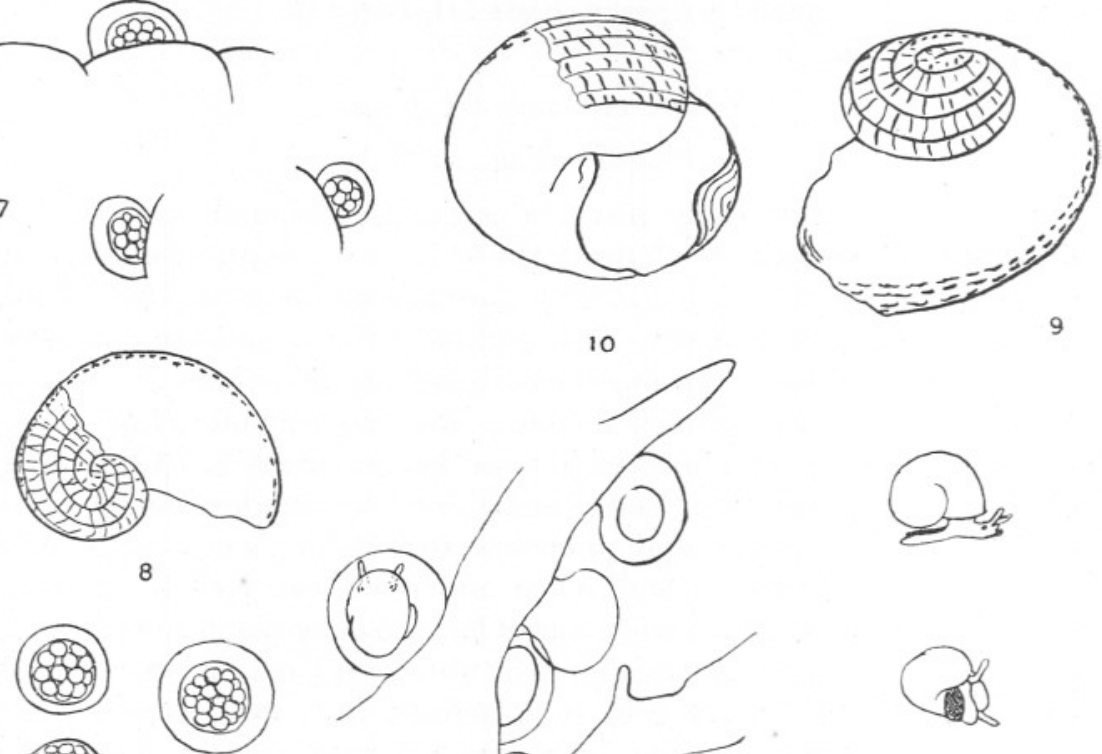

10
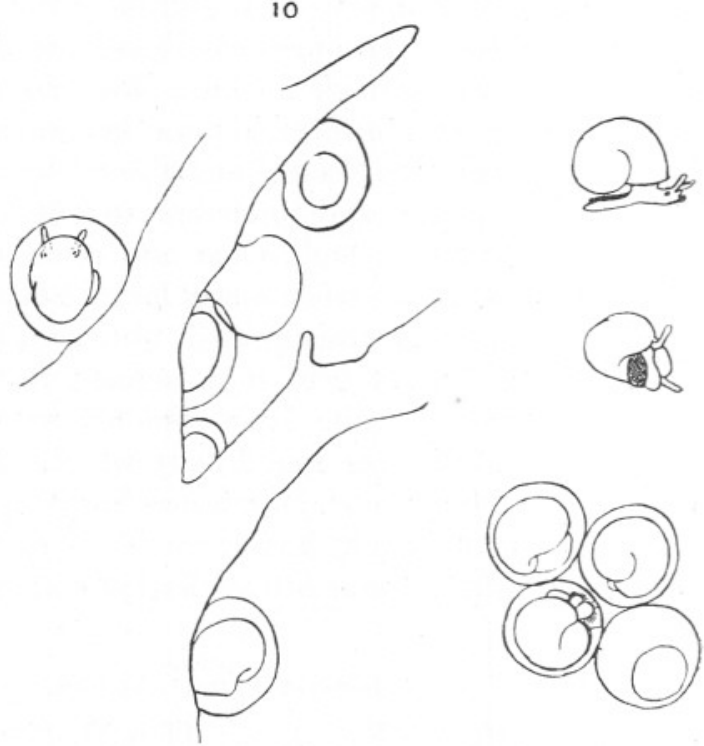

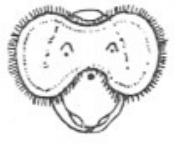

14

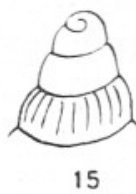

15 
larvæ from plankton reared in plunger-jars until species was distinguishable. One grew to adult size, several were three-parts grown. Eggcapsule planktonic, not unlike that of Littorina littorea but differs in shape, and size. Colourless, transparent and somewhat disc-shaped, it is rather more convex on one surface than on the other, and slightly indented near the margin, $0.18 \mathrm{~mm}$. across, $0.08 \mathrm{~mm}$. high ; contains only one egg, about $0.08 \mathrm{~mm}$. across, situated in the centre of capsule with large space as broad as itself surrounding it (Plate I, Figs. 2-6). Before larva is hatched it shows characteristic sculpture of the shell consisting of longitudinal striations with small dots in between. When hatched shell measures $0.08 \mathrm{~mm}$. across, growing quickly to $0.16 \mathrm{~mm}$. with one and a half whorls after which the spiral sculpture ceases and just above and below periphery a series of dots forms an irregular spiral band leaving upper and under surface smooth except round the incipient umbilicus where are a few dotted striæ (Plate I, Figs. 7-15). Whilst the larva is still very small with hardly more than the whorls having dotted striæ it is eaten by the young herring (Plate I, Fig. 1). Shell colourless and transparent, soon assuming a pale horn-colour, aperture dark brown. Animal and velum typically rissoid in shape. Velum gradually becoming bordered with a fine brown band just inside the outer row of cilia, sometimes absent on one side. Characteristic sculpture easily seen when shell has about 3 or $3 \frac{1}{2}$ whorls, measuring $0.48 \mathrm{~mm}$. high. Animal yellowish with a dark mass at origin of foot, purple streak on foot which is bluntly pointed and with a very flexible fore part. Tentacles long and contractile, mantle tentacle and hind tentacle above foot present, the latter very long. Larva is now ready to metamorphose and can both swim and crawl and soon loses velum (Plate I, Figs. 16-21 ; Plate II, Fig. 1). Just before it loses velum it is extremely common in the Plymouth plankton, both inside and outside Sound, especially inside, from early to late spring, hardly any being left in summer. Floating egg-capsules chiefly in late autumn and winter;

\section{PLATE IV.}

Alvania punctura, Rissoa inconspicua, unknown rissoid, Barleeia unifasciata.

(Figs. 1, 4 scale C ; 2, 3, 6,7, 11-13, 15 scale A ; 5, 8-10 scale B.)

Figs. 1-7.-Alvania punctura.

$(1,2,4)$ late veligers, shell 0.50 to $0.64 \mathrm{~mm}$. high ; (5) apex of same enlarged; (3) larva crawling, having lost velum ; (6) apex of adult shell ; (7) egg-capsules laid on shells of neighbours in bowl, capsules $0 \cdot 32-0 \cdot 48 \mathrm{~mm}$. across.

Figs. 8-10.-Shells of unknown rissoid larvæ, $0 \cdot 20$ to $0 \cdot 25 \mathrm{~mm}$. across.

FIGS. 11-12.-Egg-capsules and larvæ of Barleeia unifasciata, laid in bowl on weed, capsules $0.56 \mathrm{~mm}$. across.

Figs. 13-15.-Rissoa inconspicua.

(13) egg capsules laid in bowl, 0.48 to $0.64 \mathrm{~mm}$. across ; (14) Newly hatched larva from egg, shell $0 \cdot 10 \mathrm{~mm}$. across; (15) Apex of adult. 
young larvæ very abundant in plankton from December to February and March. Late larvæ (Plate II, Figs. 2-5) attained 6 whorls in 4 months, the adult having 7 whorls. Probably they become mature within a year. Older shells usually with brown streaks on fourth whorl running from suture, generally broken at periphery, often a brown line below last whorl, beginning at the sixth, shell sometimes clear brown without streaks. Animal with deep brown opercular lobes, very long light tentacles and processes.

Rissoa sarsii is not very well known. It was described by Lovén in 1864 from specimens found by Sars at Bergen. It is the Rissoa inconspicua var. tenuis of Forbes and Hanley (Plate LXXXII, Figs. 7-8) and the Rissoa albella var. sarsii of Jeffreys (1867). Alder found it at Rothesay a little below low-water mark and describes the animal but makes no reference to the long tentacles and posterior process (Forbes and Hanley, 1853). The only specimen reaching the adult stage at Plymouth was a brown variety having streaks only on upper whorls, last whorl with 2 dark bands above and one below periphery. Seven whorls; animal yellowish white, slightly spotted on head with brown; opercular lobes dark brown, tentacles and posterior processes light and very long. Outer lip of this specimen abnormally produced in an outstanding rib. Length $3 \mathrm{~mm}$.

\section{Cingula semistriata (Montagu).}

\section{(Plate III, Figs. 15-18.)}

A very common rissoid, occurring between tide marks and below, on weeds, hydroids, bryozoa and stones. Laid eggs in bowl on Zostera in June. Similar capsules on weeds through summer. The fixed capsules of typical form but smaller and higher in proportion to diameter than Rissoa membranacea, R. parva and R. guerini, $0.56 \mathrm{~mm}$. to $0.64 \mathrm{~mm}$. across, $0 \cdot 24 \mathrm{~mm}$. high, colourless and transparent (Plate III, Fig. 15). Eggs usually from 12 to 22 , about $0.08 \mathrm{~mm}$. across. Newly hatched larva $0 \cdot 10 \mathrm{~mm}$. across shell (Plate III, Figs. 16-17) with rather more than one whorl, no sculpture, animal and velum colourless (Plate III, Fig. 16). Later stages only recognised in plankton when nearly ready to metamorphose when there are 2 conspicuous lines below suture as in adult (Plate III, Fig. . 18); velum always colourless; 3 processes behind operculum.

\section{Cingula semicostata (Montagu).}

(Plate III, Figs. 19-24.)

Very common at Plymouth under stones between tide marks and in muddy gravel among stones further out. Eggs laid singly in jars standing in running water with gravel and small stones, in single capsules, sometimes one or two together adhering to small particles, March to May. 
Unlike the usual rissoid capsules this is oval, very tough and thickwalled, $0 \cdot 48$ to $0.64 \mathrm{~mm}$. by $0 \cdot 32$ to $0.48 \mathrm{~mm}$., usually fixed by the centre of one side (Plate III, Fig. 19). Egg enclosed in membrane, 0.24 mm. across when newly laid; velum formed within capsule and reaching a width of $0.48 \mathrm{~mm}$.; shell $0.32 \mathrm{~mm}$. across; eyes and short tentacles present and a lobe in front of eyes; foot bluntly pointed; shell faintly but quite perceptibly striated longitudinally, the striæ formed by minute dots, sometimes irregular and rough, velum gradually disappears and before hatching is lost, the animal breaking out of the capsule in the crawling stage (Plate III, Figs. 20, 21). It can easily be recognised by its likeness to the adult and is present with these at various times of year. Both shell and animal creamy white.

\section{Alvania punctura (Montagu).}

\section{(Plate IV, Figs. 1-7.)}

Very common on the outside dredging and trawling grounds, rarely nearer the coast. Obtained alive from trawl and dredging refuse. Larvæ abundant in summer and early autumn in tow-nettings usually from outside. Egg-capsules laid in bowl on the shells of one another, small and thick-walled, 0.32 to $0.48 \mathrm{~m} . \mathrm{m}$. across, rather higher than most rissoid capsules but some are typically lens-shaped. Each contains about 12-14 eggs, 0.06 mm. across (Plate IV, Fig. 7). Young from these eggs did not hatch out but minute larvæ, evidently newly hatched, are very common in summer plankton which obviously belong to this species. It is easy to recognise them for they have at first the same sculpture on the apex as Rissoa sarsii, but the part striated with spots is smaller than in that species, $0.05 \mathrm{~mm}$. across, and after this there are small raised spots on the whorls giving the shell a peculiar papillate appearance. As the larva grows the velum enlarges but is always colourless, animal yellowish white with a little brown, shell becoming a dark horn-colour. Breadth of velum in last stages more than twice length of shell (Plate IV, Fig. 1). Apical whorls of adult which constitute the larval shell are clearly seen (about $3 \frac{1}{2}$ ) after which the adult sculpture begins (Plate IV, Fig. 6). Larval shell about to metamorphose $0.64 \mathrm{~mm}$. long. Those kept in plunger-jars grew into adults.

\section{Barleeia unifasciata (Montagu).}

(Plate IV, Figs. 11, 12.)

Exceedingly common on weeds at extreme low tide in rock pools, Wembury, living on Fucus or Calliplepharis jubata, often with Rissoa parva. Unlike $R$. parva the eggs are laid singly in round capsules on the weed, adhering by only a small portion, and the velum is lost before 
hatching. Laid egg-capsules in the Laboratory on Calliplepharis, May 29th (Plate IV, Fig. 11), 0.56 mm. across, more or less round, egg 0.32 mm. across, develops into pale brown shell turning to dark brown, with small velum which soon disappears and red operculum. Shell 0.42 to $0.48 \mathrm{~mm}$. across with $1 \frac{1}{2}$ whorls, smooth and without sculpture, apex very blunt, much blunter than any rissoid known. At this size the animal hatches without a velum and crawls about. Many are to be seen on the weed with adults and young of all sizes. No posterior and no mantle tentacle. Barleeia seems to be further removed from a true Rissoa than any of the other genera now placed in the family.

Several other larvæ which resemble rissoids in shape, and almost certainly belong to this family, are to be seen in the Plymouth plankton but have not yet been identified. Among these is one with a sculptured apex with spiral striæ divided up by lines (Plate IV, Figs. 8-10). After $1 \frac{1}{2}$ whorls the sculpture is irregular dot-like markings in a few lines round periphery, animal pale yellowish with large colourless velum. This is so much like Rissoa sarsii and Alvania punctura that there is probably some relationship. It occurs with the latter usually outside the Sound in summer.

The following species occurring alive near Plymouth have not yet had their eggs and larvæ identified : Cingula fulgida, C. alderi, C. cingillus and Alvania crassa, although the adults of all but $C$. alderi are common round our coasts.

\section{LITERATURE.}

Caullery, M, and Pelseneer, P. 1910. Sur La Ponte et le développement du Vignot. Bull. Sci. de la France et de la Belgique, T. XLIV, 4th fasc.

Fischer, H. 1892. Recherches sur la Morphologie du Foie des Gasteropodes. Bull. Sci. France et Belgique, XXIV (4), Vol, III, pp. 260-346.

Forbes, E., and Hanley, S. 1853. A History of the British Mollusca, Vol. III, pp. 1-616 ; Vol. IV, pp, 1-300 and plates.

Jeffreys, G. 1867. British Conchology, Vol. IV, pp. 1-486; Vol. V, plates.

Lamy, E. 1928. La Ponte chez les Gastéropodes prosobranches. Journ. de Conchyliologie, Vol. LXXII, pp. 25-196.

Lebour, M. V. 1921. The Food of Young Clupeoids. Jour. Mar. Biol. Assoc., N.S. Vol. XII, No. 3, pp. 458-467, June. 
Lebour, M. V. 1924. The Food of Young Herring. Ibid., Vol. XIII, No. 2, pp. 325-330, November.

LovÉn, S. 1846. Index Molluscorum Litora Scandinaviæ occidentalia Habitantium. Fauna Prodromus. K. Vet. Akad. Fôrh, pp. 1-50.

Pelseneer, P. 1911. Recherches sur l'Embryologie des Gasteropodes. Mem. de l'Acad. Roy. de Belgique, 2me Sér., T. III, pp. 1-167.

Plymouth Marine Fauna. 1931. Second Edition. Marine Biological Association.

Poweld, A. W. B. 1930. New Species of New Zealand Mollusca from Shallow-water Dredgings. Trans. and Proc. New Zealand Institute, Vol. 60, Pt. 4, Dec., 1929, pp. 532-543.

Thiele, J. 1929. Handbuch der Systematisches Weichtierkunde, Part I, pp. 1-778.

Winckworth, R. 1932. The British Marine Mollusca. Journ. of Conchology, XIX, No. 7, June, pp. 211-252. 
